\title{
Survival Analysis of Hospitalized Liver Cirrhotic Patients in Jakarta: 2 Years Follow Up Study
}

\author{
Rino Alvani Gani \\ Division of Hepatobiliary, Department of Internal Medicine, Faculty of Medicine, \\ Universitas Indonesia/Dr. Cipto Mangunkusumo National General Hospital, Jakarta
}

\begin{abstract}
Corresponding author:
Rino Alvani Gani. Division of Hepatobiliary, Department of Internal Medicine, Dr. Cipto Mangunkusumo National General Hospital. Jl. Diponegoro No.71 Jakarta Indonesia. Phone: +62-21-31900924; facsimile: +62-21-3918842.E-mail: personaly@yahoo.com
\end{abstract}

\begin{abstract}
Background: The incidence of liver cirrhosis in Indonesia is increasing over time. In this study, we aim to present a 2-year survival analysis on liver cirrhotic patients using Child-Pugh and MELD score and also analyzing the most common cause of death among liver cirrhotic patients.

Method: A retrospective cohort study was used by evaluating the medical records of patients who went to internal medicine ward of Cipto Mangunkusumo Hospital during the period between 2011-2016. The inclusion criteria were all cirrhotic patient registered with a completely filled medical record. The exclusion criteria were the presence of Hepatocellular carcinoma, cholangiocarcinoma, and other form of malignancies

Results: A total of 89 patients were included in this study. The total of $75.3 \%$ of the patients were dead during the 2 years follow up with the most prevalent cause of death (COD) being infection (45.5\%). Survival analysis, showed that the survival of CP Class A were significantly better than B and C. The cut off value for 2-years mortality was CP score $>7$ and MELD score $>9$ in liver cirrhotic patients

Conclusion: The mortality rate of liver cirrhotic patients is very high with infection as the main COD. Patients with Child-Pugh score B and C have worse prognosis than Child-Pugh score A.
\end{abstract}

Keywords: liver cirrhosis, Child Pugh, 2-year survival.

\begin{abstract}
ABSTRAK
Latar belakang: Insiden sirosis hati di Indonesia meningkat dengan laju yang mengkhawatirkan. Pada studi ini kami melakukan analisis kesintasan 2 tahun pada pasien sirosis menggunakan sistem skoring Child Pugh dan MELD serta menganalisis penyebab utama kematian pada pasien sirosis.

Metode: Studi ini merupakan studi retrospektif dengan mengevaluasi rekam medis pasien pada ruang rawat inap Rumah Sakit Cipto Mangunkusumo pada periode 2011 hingga 2016. Kriteria inklusi adalah seluruh pasien sirosis yang terdaftar dan memiliki rekam medis yang lengkap dan Kriteria ekslusi adalah tidak adanya karsinoma hepatoselular, kolangiokarsinoma, dan keganasan yang lain.

Hasil: Total sebanyak 89 pasien diikutsertakan dalam studi ini. Sebanyak 75.3\% pasien meninggal dalam 2 tahun perkembangan dengan penyebab kematian paling banyak adalah infeksi (45.5\%). Sistem skoring Child Pugh dan MELD berhubungan dengan kesintasan. Nilai scoring Child Pugh $>7$ dan MELD $>7$ dihubungkan dengan resiko mortalitas 2 tahun yang tinggi.
\end{abstract}

Simpulan: Angka mortalitas pada pasien sirosis hati sangat tinggi dengan penyebab kematian terbanyak adalah infeksi. Pasien dengan Child Pugh B dan Cmemiliki prognosis yang lebih buruk dibandingkan degan Child Pugh A.

Kata kunci: sirosis hati, Child Pugh, 2-year survival 


\section{INTRODUCTION}

The total mortality of liver cirrhotic patients is now considered to be elevating worldwide. Various studies reports this as the total mortality globally or on each country around the world. Mokdad et al reported a systematical analysis on liver cirrhosis mortality throughout 187 countries from 1980-2010, Indonesia is being the $4^{\text {th }}$ highest place of the total liver cirrhosis mortality in the last decade with the total mortality of 49.224. Also, from year 1980 until 2010, the total mortality in Indonesia is keep elevating in a very alarming rate. Attempts should be done in order to prevent this premature death and also give a better evidence-based practice for the patients. ${ }^{1}$

Child Pugh scoring system and MELD has long been well established as a prognostic predictor of severity and mortality in liver cirrhotic patients as seen in several studies. ${ }^{2,3,4}$ In these studies, CP scoring especially has been shown to accurately predict the mortality outcome of liver cirrhotic patient with 2-year survival rate of $90 \%, 70 \%$, and $38 \%$ for CP class $\mathrm{A}$, $\mathrm{B}$, and $\mathrm{C}$, respectively. ${ }^{2}$ MELD score in the other hand has been proven good for predicting the 3 -month mortality of liver cirrhotic patients. ${ }^{3}$ The preferences to use between MELD and CP has long been a wide discussion. ${ }^{5}$ In Indonesia, clinicians have long adopted these prognostic predictors and using it for assessment of their liver cirrhotic patients. But, study to see the compatibility of these prognostic predictors in liver cirrhotic patients in Indonesia is not yet established.

Related to their death, patients with liver cirrhosis diagnosis could die out of several different causes, liver-related death or non-liver-related death, as mentioned in the study by Ratib et al in 2015. But, a thorough study on the various cause of death in Indonesia is not currently available. ${ }^{6}$ This study attempts to give a thorough analysis on the survival rate of hospitalized liver cirrhotic patients in Cipto Mangunkusumo Hospital, Indonesia across different $\mathrm{CP}$ and MELD classification, also to analyze the main cause of death among the patients to yet give better understanding on the natural history of this disease.

\section{METHOD}

This is a retrospective cohort study to determine the 2-year survival rate of liver cirrhosis patients in Jakarta. This study was conducted on patients admitted to internal medicine ward, Cipto Mangunkusumo hospital, Jakarta with the consecutive sampling technique. Data from medical record gathered during 2011-2016 were used. The inclusion criteria were all cirrhotic patient registered with a completely filled medical record during the period of sample collection. The exclusion criteria were the presence of hepatocellular carcinoma, cholangiocarcinoma, and other form of malignancies. The analysis was conducted using statistical package for the social sciences (SPSS) 22.0 program.

The diagnoses of liver cirrhosis were recorded from the medical data and were previously determined by the expert clinician with various data such as fibroscan, liver biopsy, ultrasonography (USG), and other modalities established as diagnostic tools for liver cirrhosis. We than look for the laboratory data to classify the viral etiology for each patient and also to categorize each patient into $\mathrm{CP}$ grouping and determine the MELD score with laboratory data immediately after the diagnoses were established.

The cause of death determined from what is written in the death certificate of each patients and using an expert opinion in which cause is the main factor that relate to the patient's death. The cause of death in the medical record was coded using the ICD-10 coding system.

Data were analyzed using SPSS program $22^{\text {nd }}$ edition. The overall survival rate of the liver cirrhotic patients was evaluated using Kaplan Meyer analysis. Evaluation also include distribution of the overall survival in terms of time and calculate the overall mean. Then subjects were grouped based on their Child-Pugh score, and MELD score and analyzed the survival for each group accordingly. Cut-off point for CP and MELD score were determine to which the patients will be categorized as 'high risk for death in the 2-year time' and compare the effectiveness of both scoring. All data presented it as tables and graph in the result section.

This study protocol was already accept by committee ethic Faculty Medicine Universitas Indonesia number 0935/UN2.F1/ETIK/2018

\section{RESULTS}

Our cohort retrospective study consists of 89 patients who were admitted to internal medicine ward, Cipto Mangunkusumo Hospital, Jakarta, Indonesia and has all completed the 2-year follow up time. The total of $71.90 \%$ of the all the patients were male. Most of them enrolled were in the range age of $>60$ years (67.40\%). The complete epidemiological data about these patients are presented in table 4.1. 
Table 1. Subjects' characteristic by 2-year follow up outcome $(n=89)$

\begin{tabular}{ll}
\hline Outcome & $\begin{array}{l}\text { Total patients } \\
\mathbf{n}(\%)\end{array}$ \\
\hline Sex & $64(71.90)$ \\
$\quad$ Males & $25(28.10)$ \\
Females & \\
Age at diagnosis (years) & $2(2.20)$ \\
31-40 & $8(9.00)$ \\
$41-50$ & $19(21.30)$ \\
$51-60$ & $60(67.40)$ \\
> 60 & \\
Etiology & $39(40.60)$ \\
Hepatitis B & $24(25.00)$ \\
Hepatitis C & $32(33.30)$ \\
Non B Non C & $1(1.00)$ \\
Hepatitis B Hepatitis C & \\
Presence of esophageal varices & $39(43.80)$ \\
Yes & $50(56.20)$ \\
No & \\
Presence of hepatocellular carcinoma & $9(10.10)$ \\
Yes & $80(89.90)$ \\
No & $18(20.20)$ \\
Child pugh classification & $47(52.81)$ \\
A & $24(27.00)$ \\
B & $54(60.67)$ \\
C & $35(39.33)$ \\
MELD score & \\
< 14 & \\
$\geq 14$ & \\
*Patient with MELD score $>14$ was considered need liver transplantation
\end{tabular}

In this study, there were 115 patients who fulfill the inclusion and exclusion criteria that we registered in this study. During our follow up, 26 of them did not come back to the hospital to do a regular visit and those patients cannot be reached by phone and considered loss of follow up. The remaining 89 subjects can be analyzed.

Out of the total of 89 subjects, 67 of them $(75.3 \%)$ were died during the 2-year follow up. From the overall Kaplan Meier graph (Figure 1), $50 \%$ of all the patients had died after around 5-month of follow up. At the beginning of the follow-up period, many patients died after only in the first month of their diagnosis (the graph shows a very steep decline from 1 cumulative probability in 0 -month to about 0.7 in the first month of follow-up). After the whole two years follow up, the cumulative probability was 0.25 . From all the deceased subjects, the mean survival time was 10 months after the diagnoses. The mortality rate were 377 death/1000 patients each year.

From the Kaplan Meier graph and the log-rank test analysis of survival rate for liver cirrhotic patients according to their CP score (Figure 4.2a), there was a statistically significant difference of the survival rate between $\mathrm{CP}$ A and B; and also between CP A and C ( $p<$ 0.001 for both), while there is no significant difference between the CP B and C ( $p>0.05)$.

After the total of 2-years follow up, CP A, B and score have cumulative survival probability of $91.7 \%$, $13.9 \%$, and $5.6 \%$, respectively. The cumulative probability trend was decreasing over time for $\mathrm{CP} B$ and $\mathrm{C}$, while remain stable after the 2 months in $\mathrm{CP}$ A patients. The progressive decline in $\mathrm{CP} B$ and $\mathrm{C}$ during the first months of follow-up were quite rapid, for both has reached the cumulative survival of 0.5 in 3-4 months follow-up.

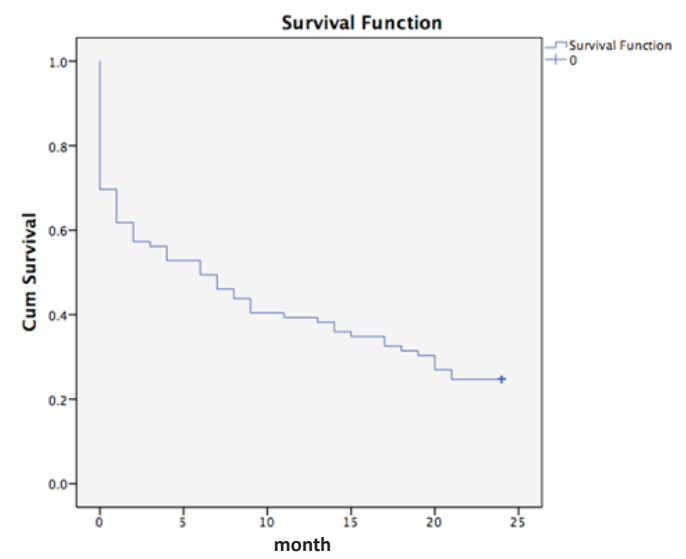

Figure 1. Kaplan Meier analysis for overall survival time
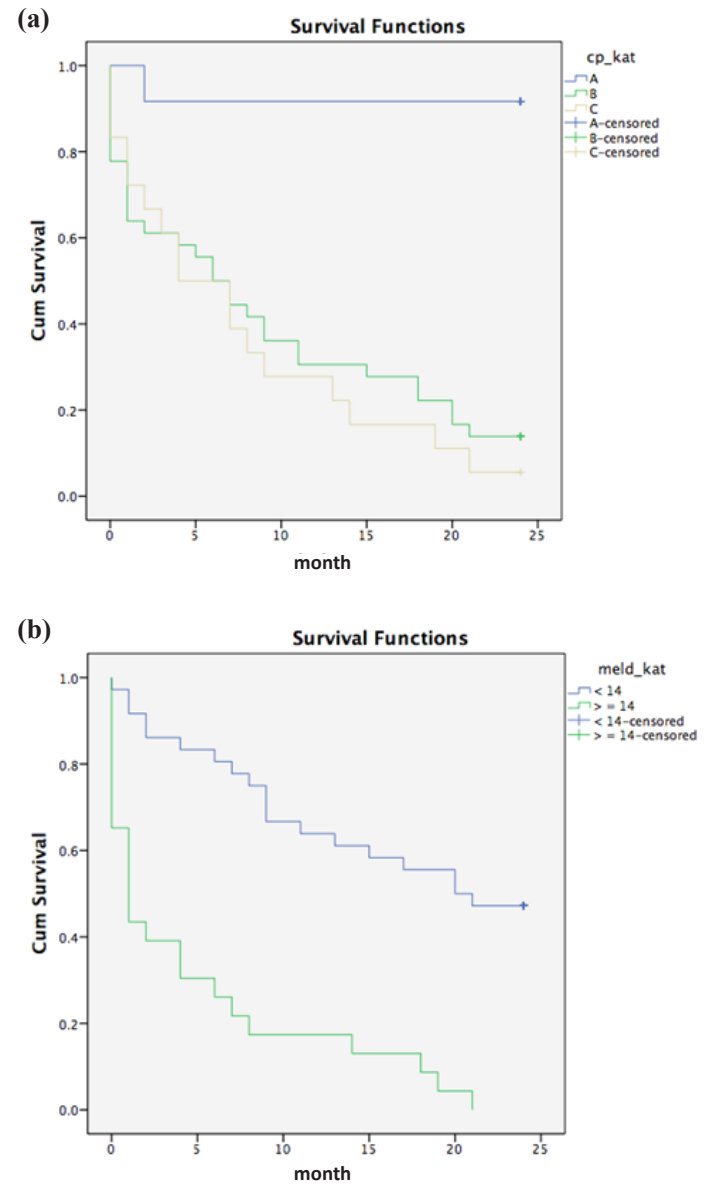

Figure 2. (a) Kaplan Meier analysis for each CP score class; (b) Kaplan Meier analysis for MELD score of $<14$ and $\geq 14$ (based on the liver transplantation indication) 

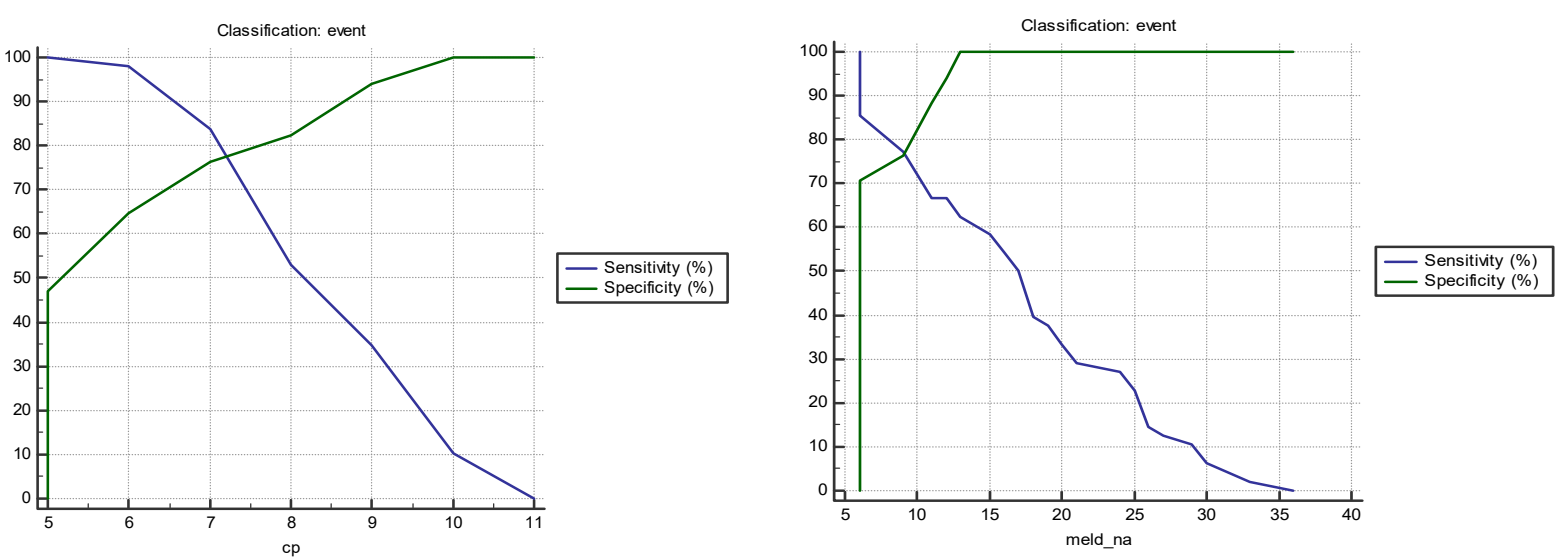

Figure 3. (a) Sensitivity-specificity graph analysis for CP score; (b) Sensitivity-specificity graph analysis for MELD score

The survival rate analysis for patients with the indication of liver transplantation (MELD $\geq 14$ ) compared to those without it $($ MELD $<14)$ shows that both group has a statistically significant difference in terms of survival ( $\mathrm{p}<0.05$, Figure $4.2 \mathrm{~b}$ ). In the MELD score $<14$ ), the 2-year cumulative probability was 0.5 ; while within the group with MELD $\geq 14$, no subjects survived after $21^{\text {st }}$ months of follow-up. All of the liver cirrhotic patients in this category did not receive liver transplantation because no established liver transplant program yet available. Patients with MELD $\geq 14$ achieved the 0.5 survival cumulative probability only in 2-3 months after the diagnosis.

A bivariate analysis was conducted to see the relation between gender, ages, serum bilirubin level, serum albumin level, INR, the presence of esophageal varices, the presence of ascites, the presence of hepatic encephalopathy, and the presence of hepatocellular carcinoma to the outcome of mortality. It showed that sex, serum bilirubin level, serum albumin level, and INR are the significant risk factors for mortality. Multivariate analysis from that factors showed only the serum bilirubin level and serum albumin level are considered as independent risk factors for mortality with the adjusted OR of 3.113 (95\% CI: $1.356-7.147$ ) and 5.782 (95\% CI: 1.922 - 17.392), respectively. These factors already included in CP score (albumin) or MELD score (bilirubin) which were already proved as the independent risk factor for mortality $(\mathrm{p}<0.001)$.

Statistical analysis for CP and MELD score to predict the 2-year mortality for liver cirrhosis patients showed that CP score $>7$ was consider as the best value to predict the 2-year mortality with the sensitivity of $83.67 \%$ and specificity of $76.47 \%$. As for MELD score, MELD score $>9$ was the best predictor for 2-year mortality with the sensitivity of $77.08 \%$ and specificity of $76.47 \%$.
The comparison between CP and MELD score to predict the 2-year mortality in a liver cirrhotic patients, give the result as follow:

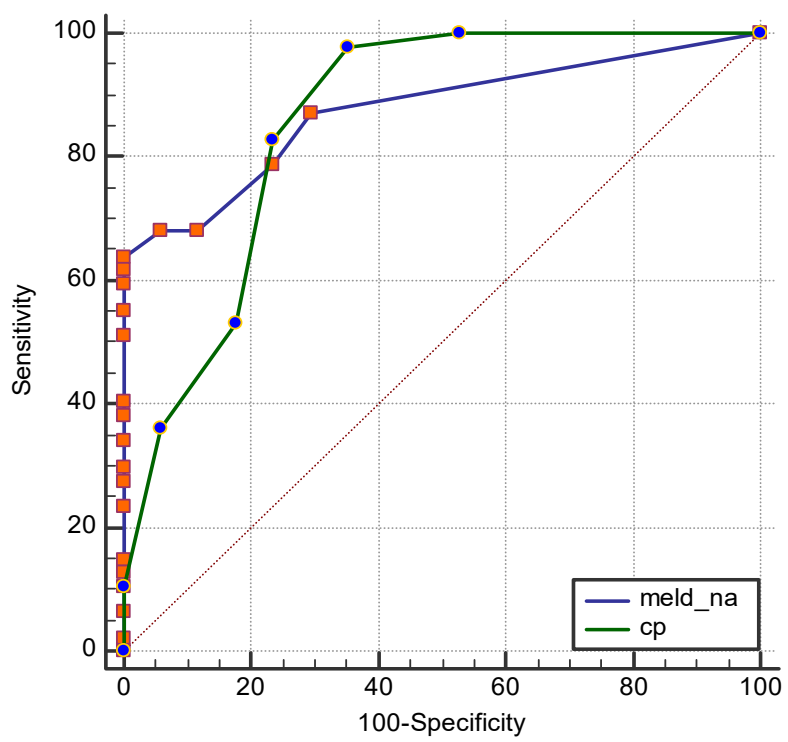

Figure 4. AUROC analysis comparison between CP scoring and MELD scoring

From the graph above, the AUC for CP score is 0.858 while the MELD score is 0.875 . Both the AUC do not differ significantly, although the both give a high value for the ability to predict the 2-year mortality in liver cirrhotic patients.

Table 2. Causes of death among liver cirrhotic patients

\begin{tabular}{lc}
\hline Cause of death & $\begin{array}{l}\text { Patients } \\
\mathbf{n}(\%)\end{array}$ \\
\hline Infection & $30(45.5)$ \\
Bleeding & $16(24.2)$ \\
Liver failure & $14(21.2)$ \\
Hepatic encephalopathy & $5(6.1)$ \\
Cardiac arrhytmia & $1(1.5)$ \\
Chronic kidney failure & $1(1.5)$ \\
\hline Total of deceased patients & $67(100)$ \\
\hline
\end{tabular}

The total of 67 subjects were dead during the 2-year follow up. From the table 4.2 it can be seen that the 
cause of death among those liver cirrhotic patients were varied with the highest was infection followed by gastrointestinal bleeding and liver failure.

\section{DISCUSSION}

The overall survival rate in 2-years follow up in this study of 89 adult hospitalized patients admitted to Cipto Mangunkusumo Hospital is $75.3 \%$ with the mortality rate calculated to be 377 deaths per 1,000 patients per year. As we can see on the Kaplan Meier graph, after the survival probability on 1-year after the diagnosis is $40 \%$. Compare to the study done in Danish cirrhotic patients by Jepsen et al, on 2008, whose survival probability during 1-year follow up was only $65 \%$, this result is clinically different. ${ }^{7}$ This result is also considered much lower than other result obtained from different studies in several countries; such as $85 \%$ in England and Cuba with $65 \% .^{3,8}$

This study aims to analyze the survival rate of liver cirrhotic patients in each Child Pugh classification. From the graph we can see that the survival rate between $\mathrm{CP}$ A and B; also between CP A and C is significantly different. While, the survival rate between $\mathrm{CP} B$ and $\mathrm{C}$ is not significantly different. This result is not correlate well with previous studies, such as the on conducted by Marcia et al. They reported a significant difference between all CP groups. ${ }^{3}$ D'Amico et al in their classic study of liver cirrhotic patients in Sissili also report a significant difference between each CP groups. ${ }^{2}$ But, there is also a study who found that there is no significant difference among the CP score classification..$^{9,10}$ This could lead us to the assumption that CP Score is not very strong in differentiating the mortality prediction among patients. This is also supported by the fact that in the 4 months, $\mathrm{CP}$ class $\mathrm{B}$ and $\mathrm{C}$ is overlapping in their survival cumulative probability with even higher for $\mathrm{CP} C$. So we can see that $\mathrm{CP}$ is not a very effective predictive value for short term mortality.

The 2-year survival cumulative probability of $91.7 \%, 13.9 \%$, and $5.6 \%$, respectively, for CP A, B, and $\mathrm{C}$ in this study is considered much lower compared to other studies such as Marcia et al in Cuba during 2004-2011, with the 3-year cumulative probability of $80.4 \%, 69.6 \%$, and $31 \% .{ }^{3}$ D'Amico's Sissilian study also possess a better cumulative probability with $90 \%$, $70 \%$, and $38 \%$ for 2 -year follow-up time. Our CP A class patients have a higher result of $1.7 \%$, but it is not considered statistically nor clinically different. ${ }^{2}$

Another parameter that we saw was the MELD score. Here, we divide the MELD score into 2 categories, which are the score with 14 or above 14 ( $\geq 14)$ and the one or below $(\leq 14)$. This classification, as mentioned above based on the cut-off for liver transplantation indication. As we can see from the Kaplan Mayer graph, for MELD score $>14$ the 2-year survival cumulative probability is $0 \%$, while below it are $50 \%$. The two group is significantly different on this matter. The availability and feasibility to perform liver transplantation in our center is still currently limited. So for all this patients with MELD $\geq 14$ (39\%) did not gain the liver transplantation with various reasons. This could be an evaluation for the need of liver transplantation procedures in the future to give a better prognosis for liver cirrhotic patients.

In this study, we analyze factors that relate with mortality within the 2-years follow-up time. And after conducting a multivariate analysis we only get serum bilirubin level and serum albumin level as independent risk factors. Several studies also confirm this analysis. Both these factors are included in CP Scoring system and also MELD Scoring system. Also our statistical analysis confirmed that both the scoring system is significantly related with mortality as also can be seen from the log rank test in the Kaplan Meier analysis.

Previous studies have demonstrates varied factor that correlate to the number of mortality in a liver cirrhotic patients. Magliochetti et al for example, reports that CP Score, the presence of hepatic encephalopathy, albumin level, and GEV hemorrhage as independent risk factors for mortality. ${ }^{11}$ In another study also Patch et al. demonstrates the relation between moderate to severe ascites, need for ventilation, white blood cell count, platelet count, partial thromboplastin time, and creatinine and mortality. ${ }^{12}$ In another study with the population liver cirrhotic patients registered in intensive care unit found that Increased white blood cell count, increased hemoglobin and decreased prothrombin concentration, and elevated creatinine, as independent risk factors for mortality in liver cirrhotic patients. ${ }^{13}$ Also in a study involving 403 liver cirrhotic patients by Conn et al shows that the presence of variceal bleeding, renal failure with raised serum creatinine, postgastroscopy re-bleeding, and presence of HCC and PSE as independent predictors and risk factors of mortality. ${ }^{14}$

In our study, it has been mentioned that we get the serum albumin level, serum bilirubin level, CP Score, and MELD score as the predictor for mortality. This result has been widely established. But here, we also analyze which score in the CP Scoring system and MELD scoring system that could better separate patients with the higher possibility of death during the 
2-years follow up, and the result is we got the cut off of $>7$ for CP score and $>9$ for MELD score. Both of this cut-off point had quite a high sensitivity and specificity of $83.67 \%$ and $76.47 \%$ for the CP Score; while for the MELD Score is $77.08 \%$ and $76.47 \%$. Several studies has also been try to demonstrate a certain cut off value for predicting high-risk mortality patients. Angermayr et al in their study among liver cirrhotic patients who underwent TIPS procedure found the cut-off point of CP $>11$ and MELD $>14$ for predicting short-term mortality (3 months). ${ }^{9}$ Yu et al who conducted studies in liver cirrhotic patients in Philippines get the cut-off values for predicting long term mortality of 7.32 for $\mathrm{CP}$ score and 7.89 for MELD score. ${ }^{15}$ Peng et al also gives a higher cut-off value for short-term in-hospital mortality of CP $>11$ and MELD $>25.7 .{ }^{5}$ An established article on the cut-off value for predicting long-term mortality is still lacking. Therefore we think that if we can get a much more samples in the future for our study, than the result could be widely accepted.

From the total of our 67 liver cirrhotic patients, as we can see that most of them (45.5\%) having infection as the cause of death. This data we have correlate with studies that also mention liver cirrhotic patients' susceptibility to infection and state of immune dysfunction that lead to the presence of infection and death related. Bonel et al reported that bacterial infection can occur in $32-34 \%$ of all liver cirrhotic patients that were admitted to hospital. ${ }^{16}$ Other studies have quite varied result with the incidence of bacterial infection in liver cirrhotic patients ranging from $7-40 \% .{ }^{17}$ From our result it is quite clear that the number of infection in liver cirrhosis patients is very high that it become the number 1 cause of death. Moreover, to see a more detailed picture, most of the infection in our patients is pneumonia and SBP. These are the 2 major infections that could lead patients into septic and even shock. ${ }^{18}$ Although in many studies it has been widely accepted that SBP is the most common bacterial infection, this is different with our study, which placed pneumonia in the first rank.

Infection occurs more often in liver cirrhotic patients compare to hospitalized patients by other causes. This fact was reported by Bonel et al that mentioned the incidence of bacterial infection of $32-34 \%$ in liver cirrhotic patients compared to $5-7 \%$ in the overall hospitalized patients. ${ }^{16}$ This is thought to be related with cirrhotic-associated immune dysfunction syndrome which explains that liver cirrhotic patients is decreasing in their ability to clear cytokines, bacteria, and endotoxin from the circulation.
Beside that, liver cirrhosis also cause a dysfunction in Reticuloendothelial system, decreased neutrophil mobilization, and also decreased phagocytic activity. Patients with liver cirrhosis often accompanied by malnutrition that also lead to decreased immune function. The medication for liver cirrhotic patients also have some immunosuppressive effect that impair the immune system even more. ${ }^{16,18}$

As been said before, pneumonia and SBP is the two most common infection in hospitalized liver cirrhotic patients. Hospitalized acquired pneumonia also has a high incidence in our center. Patients with liver cirrhosis are more prone to have HAP due to procedures such as endotracheal intubations. These infections will then lead patients into SIRS. SIRS and cirrhosis is interlinked with each other and one condition could worsen the other. SIRS in patients with liver cirrhosis could easily fall into septic shock and if it cannot be decompensated well will easily cause death. ${ }^{19}$

The high incidence of bacterial infection in liver cirrhotic patients has caused clinician to think more about the prevention effort on this matter. As SBP has long been widely discussed and reviewed in according to this subjects, the use of antibiotic as a prophylaxis for SBP in liver cirrhotic patients with ascites has been applied currently. While for other infection, some effort has been reviewed such as prophylaxis broad spectrum antibiotic and the effectiveness of pneumococcal vaccination in preventing pneumonia in liver cirrhotic patients. In this moment, there has not been a guideline that recommend the use of broad spectrum antibiotic for liver cirrhotic patients. Several case reports has observed a deteriorating adverse events related to this matter and also the higher risk antibiotic resistance with this procedure. Beside that, the pathogen is so varied and a single antibiotic prophylaxis will not cover it all, so its effectiveness will not be maximized. That is why we have not seen guideline which supports this practice. However, the attempts to prevent bacterial infection can also be done through nutritional aspects and behavioral interventions that will minimize pathogen-specific complications. ${ }^{17,18,20}$

In several report, HCC is often associated with a high mortality rate in liver cirrhotic patients. From our study, which patients dominantly fall into CP B and $\mathrm{C}$, the presence of $\mathrm{HCC}$ was only found in $10.10 \%$ of all the patients. This result was thought to relates with a short follow-up time. Also, as been widely accepted from several studies, the development of liver cirrhosis into HCC is varied in its duration and also depends on the initial hepatitis viral infection. ${ }^{20,21}$ 
In the study by Ratib et al, it is reported that patients with liver cirrhosis, both in compensated and decompensated state are more likely to die from liver-related causes than any other causes, when compared with the general population. In line with this statements, in our study it was demonstrated that the total of 35 patients $(50.7 \%)$ were deceased from the liver related cause such us GI bleeding from ruptured esophageal varices, liver failure, and hepatic encephalopathy. ${ }^{6}$

From this study, we get the data that in the more severe liver cirrhotic patients, such as in CP C class, the cause of death is mostly due to liver-related cause which accounts for $60 \%$ of the total deceased patients compared to only $40 \%$ among them who died out of infection. In patients with CP B also, liver-related mortality is higher than any other cause with $(55.5 \%)$.

It should be noted that there are some limitations in our study. First, our sample is not very large. In the future we hope that we can improve the quality of this study by adding more patients registered.

\section{CONCLUSION}

From this study, we can see that the prognostic of liver cirrhosis patients in Indonesia, Jakarta especially is considered to be lower than patients from another region by the study comparison. Infection is the most common cause of death one theory is due to the immune dysfunction occurred in liver cirrhotic patients. CP and MELD scoring system has been widely used in the clinical setting to see the prognosis of liver cirrhotic patients, from our evaluation, $\mathrm{CP}$ classification is not very effective to be used in our patients. Here, the cut-off value of $\mathrm{CP}>7$ and MELD $>9$ is considered a better predictor for long-term mortality, which is within 2-years follow-up time.

\section{REFERENCES}

1. Mokdad AA, et al. Liver cirrhosis mortality in 187 countries between 1980 and 2010: a systematic analysis. BMC Medicine 2014; $12: 145$.

2. D'Amico G, Garcia-Tsao G, Pagliaro L. Natural history and prognostic indicators of survival in cirrhosis: a systematic review of 118 studies. J Hepatol 2006;44:217-31.

3. Samada M and Hernandez JC. Prognostic factors for survival in patients with liver cirrhosis. Liver Transplantation - Basic Issues 2012;1:125-143.

4. Wiesner R, Edwards E, Freeman R, Harper A, Kim R, Kamath $\mathrm{P}$, et al. Model for end-stage liver disease (MELD) and allocation of donor livers. Gastroenterology 2003;124:91-6.

5. Peng Y, Qi X, Guo X. Child-Pugh versus MELD score for the assessment of prognosis in liver cirrhosis: a systematic review and meta-analysis of observational studies. Medicine 2016;95:1.

6. Ratib S, Fleming KM, Crooks CJ, Walker AJ, West J. Causes of death in people with liver cirrhosis in England compared with the general population: a population-based cohort study. Am J Gastroenterol 2015;110:1149-58.

7. Jepsen P, Vilstrup H, Andersen PK, Lash TL, Sorensen HT. Comorbidity and survival of Danish cirrhosis patients: a nationwide population-based cohort study. Hepatology 2008;48:214-20.

8. Roberts SE, Goldacre MJ, Yeates D. Trends in mortality after hospital admission for liver cirrhosis in an English population from 1968 to 1999. Gut 54:1615-21.

9. Angermayr B, Cejna M, Karnel F, Gschwantler M, Koenig F, Pidlich J, et al. Child-Pugh versus MELD score in predicting survival in patients undergoing transjugular intrahepatic portosystemic shunt. Gut 2003;52:879-85.

10. Kim WR, Poterucha JJ, Wiesnwer RH, Larusso NF, Lindor KD, Petz J, et al. The relative role of the Child-Pugh classification and the Mayo natural history model in the assessment of survival in patients with primary sclerosing cholangitis. Hepatology 1999;29:1643-8.

11. Magliocchetti N, Torchio P, Corraco G, Arico S, Favilli S. Prognostic factors for long-term survival in cirrhotic patients after the first episode of liver decompensation. Ital J Gastroenterol Hepatol 1997;29:38-46.

12. Patch D, Nikolopoulou V, McCormick A, Dick R, Armonis A, Wannamethee G. Factors related to early mortality after TIPS for failed endoscopic therapy in acute variceal bleed. J Hepatol 1998;28:454-60.

13. Nafeh HM, Abdelmoneim SS, Hassany SM, Swifee YM. Risk factors and outcome in ICU patients with end-stage liver disease. J Arab Soc Med Res 2014;9:33-9.

14. Fsd Conn HO. Quantifying the severity of hepatic encephalopathy. In: Conn HO, Bircher J, eds. Hepatic encephalopathy: syndromes and therapies. Bloomington, Illinois: Medi-Ed Press 1994.p.13-26

15. Yu II , Abola L. Predicting Prognosis among Cirrhotic Patients: Child-Pugh Versus APACHE III Versus MELD Scoring Systems. Phil J Gastroenterol 2006;2:19-24.

16. Bonnel AR, Bunchorntavakul C, Reddy KR. Immune dysfunction and infections in patients with cirrhosis. Clin Gastroenterol Hepatol 2011;9:727-38.

17. Christou L, Pappas G, Falagas ME. Bacterial infection-related morbidity and mortality in cirrhosis. Am J Gastroenterol 2007;102:1510-7.

18. Bruns T, Zimmermann HW, Stallmach A. Risk factors and outcome of bacterial infections in cirrhosis. World $\mathrm{J}$ Gastroenterol 2014;20:2542-54.

19. Mahandaru D, Wardhana A. Nosocomial infection in Burn Unit of Cipto Mangunkusumo Hospital, Jakarta 2012;1:352-6.

20. Fleming KM, Aithal GP, Card TR, West J. All-cause mortality in people with cirrhosis compared with the general population: a population-based cohort study. Liver International 2012;32:79-84.

21. Leon DA, McCambridge J. Liver cirrhosis mortality rates in Britain from 1950 to 2002: an analysis of routine data. The Lancet 2006;367:52-6. 